\title{
Determinants of spatial differentiation of labour markets in Ukraine
}

\author{
Paweł Dykas, ${ }^{a}$ Tomasz Misiak, ${ }^{\mathrm{b}}$ Tomasz Tokarskic
}

\begin{abstract}
The aim of this paper is to present the differentiation of the situation in regional labour markets in Ukraine in the years 2004-2017. The analyses carried out for this purpose concern the diversity and dynamics of macroeconomic variables, such as labour productivity (measured by GDP per worker), wages, and unemployment rates.

Moreover, using panel data from the Statistical Office of Ukraine, the authors estimate the parameters of a set of equations based on increments and levels by means of the system estimator of the generalized Blundell and Bond moments method from 1998. The estimates concern the parameters of equations describing the main determinants of the increase in unemployment rates and wages for the entire Ukrainian economy - both Left- and Right-Bank Ukraine.
\end{abstract}

Keywords: unemployment rate, labour productivity, wages, Ukrainian economy, labour market JEL: J01, J31, J64, J69, R23

\section{Introduction}

The aim of the analyses carried out in the paper is to assess the spatial differentiation of the situation in regional labour markets in Ukraine in the years 2004-2017. The choice of this period resulted from the availability of relevant statistical data (by region) on the website of the Ukrainian statistical office. ${ }^{1}$

The analyses concern the diversity and dynamics of such macroeconomic variables as labour productivity (measured by GDP per worker), wages and unemployment rates. In addition, the paper presents equation estimates of increases in unemployment rates and wages, using panel data for Ukrainian regions.

\section{General characteristics of Ukrainian oblasts}

According to the 1996 Constitution of Ukraine (Chapter IX), the country is divided into 24 oblasts (regions), the Autonomous Republic of Crimea, further referred to as 'ARK' with its capital Simferopol, and 2 special status cities: Kyiv and Sevastopol (see Map 1). Since 2014, the Autonomous Republic of Crimea and Sevastopol have been occupied by Russia, as a result of the Euromaidan of 2013/2014.

\footnotetext{
a Jagiellonian University, Department of Mathematical Economics, e-mail: pawel.dykas@uj.edu.pl (corresponding author), ORCID: https://orcid.org/0000-0002-3317-941X.

${ }^{b}$ Rzeszow University of Technology, Department of Economics, e-mail: tmisiak@prz.edu.pl, ORCID: https://orcid.org/0000-0002-4296-0291.

c Jagiellonian University, Department of Mathematical Economics, e-mail: tptt@wp.pl, ORCID: https://orcid.org/0000-0002-9551-0892.

${ }^{1}$ http://www.ukrstat.gov.ua/.
} 
The Ukrainian oblasts are divided into 5 groups (for more details see e.g. Chugaievska et al., 2017, Chugaievska and Tokarski, 2018 or Tokarski et al., 2019). These groups consist of the following:

- 8 regions of Western Ukraine (Khmelnytsky, Chernivtsi, Ivano-Frankivsk, Lviv, Rivne, Ternopil, Volyn, and Zakarpattia);

- Northern Ukraine (city of Kyiv with its surroundings: Chernihiv, Kyiv region, Sumy, and Zhitomyr regions);

- 4 regions of Eastern Ukraine (Kharkiv, Donetsk, Luhansk, ${ }^{2}$ and Zaporozhsky regions);

- South Ukraine (Autonomous Republic of Crimea, Kherson, Mikolaiv, Odessa, and Sevastopol oblasts);

- 5 oblasts of Central Ukraine (Cherkassy, Dnipropetrovsk, Kirovograd, Poltava, and Vinnytsia).

Map 1. Administrative division of Ukraine

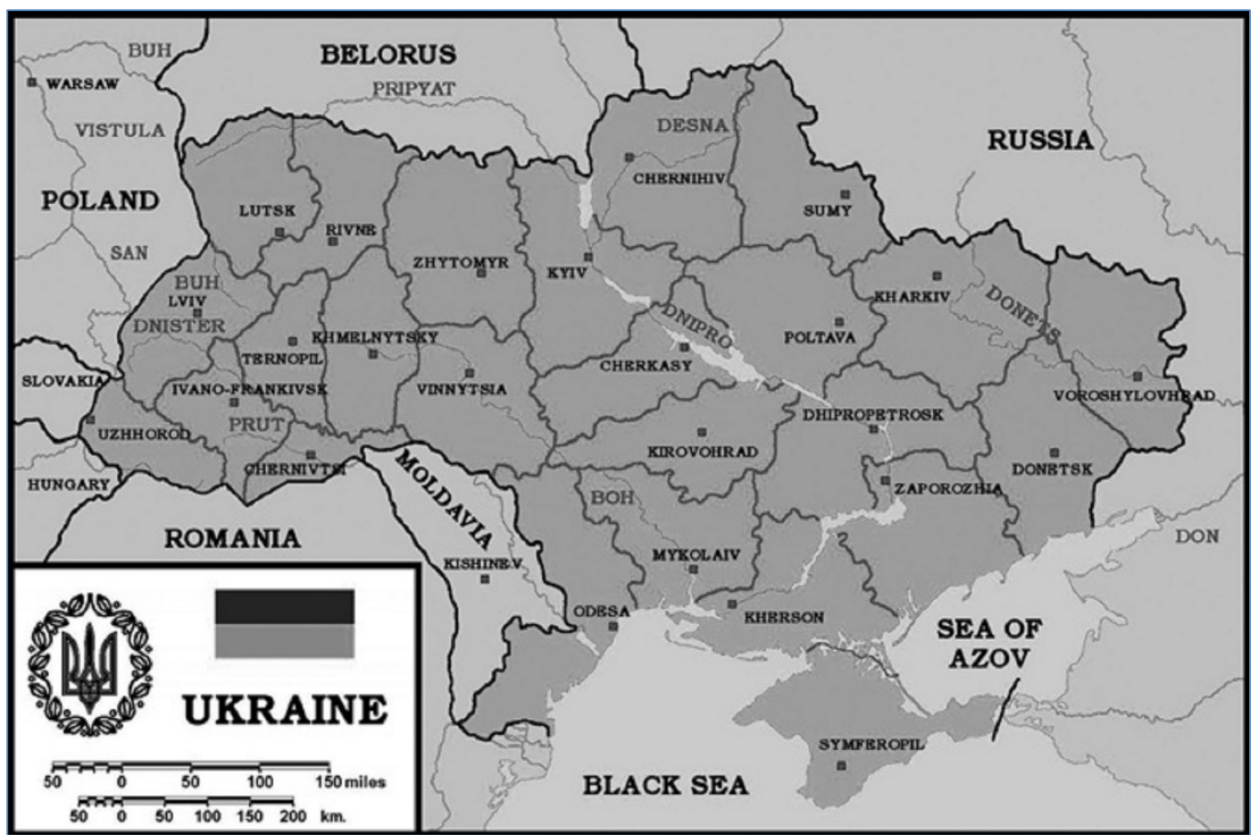

Source: http://www.uec.com.pl/pl/ukraina/informacja_o_obwodach.

Before World War I, the Volhynia and Rivne Oblasts (situated in Volhynia) were a peripheral part of the Russian Empire, while in the interwar period this territory

\footnotetext{
${ }^{2}$ The Donetsk and Luhansk regions constitute an industrial area called the Donbass. The abbreviation Донбас (Russ. Донбасc) comes from the name Донецькийвугільнийбасейн (Russ. Донецкийкаменноуго льныйбассейн), or the Donetsk Coal Basin.
} 
belonged to Poland, just like the Lviv, Ivano-Frankivsk, and Tarnopol Oblasts, which until 1918 were the north-easternmost parts of the Kingdom of Galicia and Lodomeria (part of the Austrian Empire), but in the interwar period also belonged to Poland. In the years 1849-1918, the Chernivtsi Oblast of Bukovina (the Duchy of Bukovina) belonged to the Austrian Empire, and between World War I and World War II to Romania, while the Zakarpattia Oblast was part of the Kingdom of Hungary until 1918, and in the interwar period fell under the rule of Czechoslovakia. Before World War I, the Khmelnytsky Oblast in Podolia belonged to Russia, and in the interwar period became a part of the Soviet Union. In the period between the end of World War II and Ukraine regaining independence (in 1991), all the oblasts of Western Ukraine were part of the Ukrainian Soviet Socialist Republic (part of the Soviet Union).

In short, for 200 years the regions of Western Ukraine were peripheral areas of the countries they belonged to. This situation was the reason for Western Ukraine's social and political instability, and hindered its economic development (cf. e.g. Hrycak, 2000; Serczyk, 2001; Hud, 2018).

In the $19^{\text {th }}$ and $20^{\text {th }}$ century, the oblasts belonging to the remaining groups of districts (in particular the districts located in Left-Bank Ukraine ${ }^{3}$ and the coastal districts of Odessa, Mykolaiv, and Kherson) were politically and economically much more closely integrated with the Russian Empire, and later with the Soviet Union, than Western Ukraine. Therefore, their history and social, political, and economic relations were very different from that of Western Ukraine (after Hrytcak, 2000; Serczyk, 2001; Hud, 2018).

\section{Differences in labour productivity, wages and unemployment rates in Ukraine}

Map 2 shows the regional variation in labour productivity in Ukraine between 2004 and 2017. ${ }^{4}$ The trajectories of this variable in groups of oblasts are illustrated in Figure 1. Map 2 and Figure 1 present the following information (see also Pustovoit, 2016; Chugaievska et al., 2017; Tokarski et al., 2019): ${ }^{5}$

\footnotetext{
${ }^{3}$ Left-Bank Ukraine (Right-Bank Ukraine) is the part of Ukraine that lies to the left (right) of the largest Ukrainian river - the Dnieper.

${ }^{4}$ The data on the Autonomous Republic of Crimea and Sevastopol illustrated in Maps 2-4 are the average values of the analysed variables from 2004-2013 (due to the annexation of the Crimean Peninsula by Russia in 2014).

${ }^{5}$ All the figures analysed below, expressed in monetary units, are converted into fixed prices as of 2016. In 2016, the nominal GDP of Ukraine totaled 2,385.4 billion hryvnias, while the Polish GDP amounted to $1,861.1$ billion PLN. The real GDP of Ukraine at PPP and fixed prices in 2010 was equal to 682.5 billion dollars, while the Polish GDP to 925.8 billion dollars (https://w3.unece.org/). Therefore, the dollar was (according to PPP) equal to 3.495 hryvnias or 2.010 PLN. Hence the conclusion that 100 hryvnias in 2016, including PPP, amounted to PLN 57.5.
} 
- the highest level of labour productivity was recorded in Kyiv (364,400 hryvnias). The Dniepropetrovsk (172,100 hryvnias) and Poltava (164,900 hryvnias) Oblasts in Central Ukraine, Donetsk (157,600 hryvnias) in Eastern Ukraine and the Kiev Oblast (147,000 hryvnias) in the north of Ukraine also demonstrated a high level of labour productivity for Ukrainian conditions;

- the lowest labour productivity, i.e. below 80,000 hryvnias, was recorded in the Kherson Oblast (77,700 hryvnias) in Southern Ukraine, the Ternopil Oblast (74,700 hryvnias), the Zakarpattia Oblast (69,200 hryvnias), and in the Chernivtsi Oblast (62,900 hryvnias) in Western Ukraine;

- Left-Bank Ukraine and the Odessa and Mykolaivs'ka Oblasts are characterised by higher technical employment infrastructure and often by stronger gravitational effects than Right-Bank Ukraine (Chugaievska et al., 2017). Therefore, the level of labour productivity in these areas was generally higher than in Western Ukraine;

Map 2. Labour productivity in the oblasts in $2004-2017^{\text {a }}$ (thousands of hryvnias, 2016 prices)

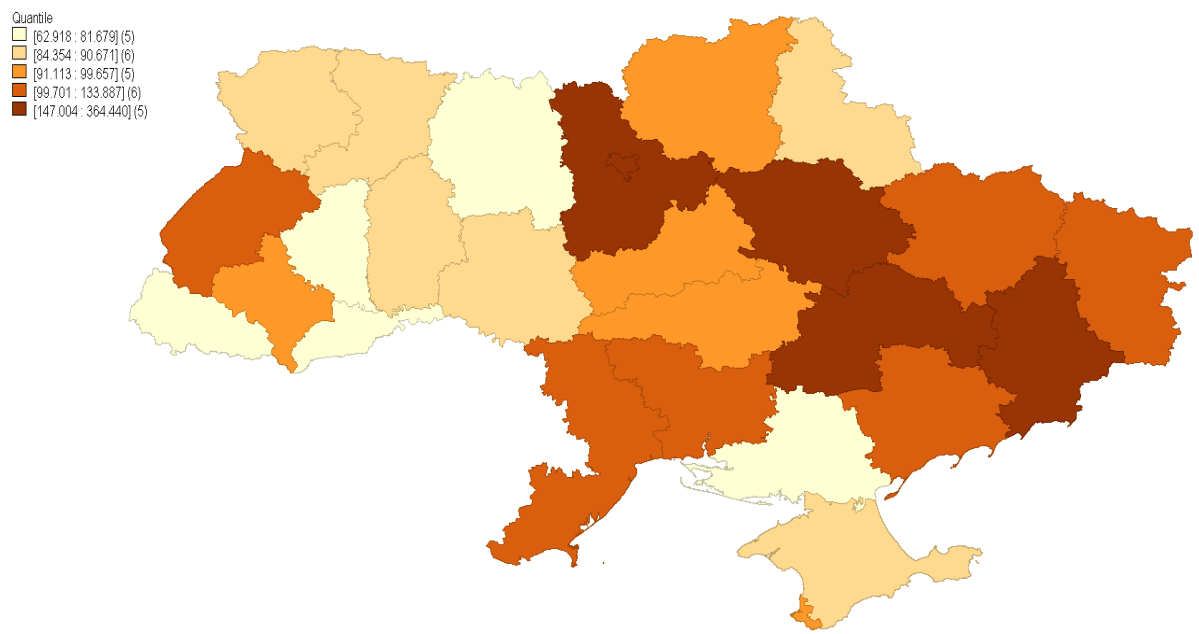

a For ARK and Sevastopol, 2004-2013.

Source: authors' calculations based on data from www.ukrstat.gov.ua.

- relatively large economic potential of the Ukrainian economy (measured by GDP per working person) was concentrated in Left-Bank Ukraine (Kyiv City, the Kyiv Oblast, Dnipro City, Donbas, Kharkiv, Zaporozhye), in two coastal oblasts (Odessa and Mykolaiv), and in the Lviv Oblast in Western Ukraine. Kyiv is Ukraine's centre of administration, transport, etc. Ukraine's financial services are located in the city of Dnipro, which is another centre for political, cultural, and educational 
life in Central Ukraine. Kharkiv, Zaporozhye and Donbass are the main regions where Ukrainian heavy industry and mining are located. The high level of economic development of the Odessa Oblast results mainly from the operations of the Odessa sea port. An important transport hub (road, railway, sea, river, and air transport) is located in Nikolayiv and the Nikolayiv Oblast in the south of Ukraine, while Lviv is by far the most economically developed city with the largest population in the western part of the country (cf. also Chugaievska and Tokarski, 2018; Chugaievska et al., 2017 or Tokarski et al., 2019);

Figure 1. Labour productivity in groups of regions (in thousands of hryvnias, prices as of 2016)

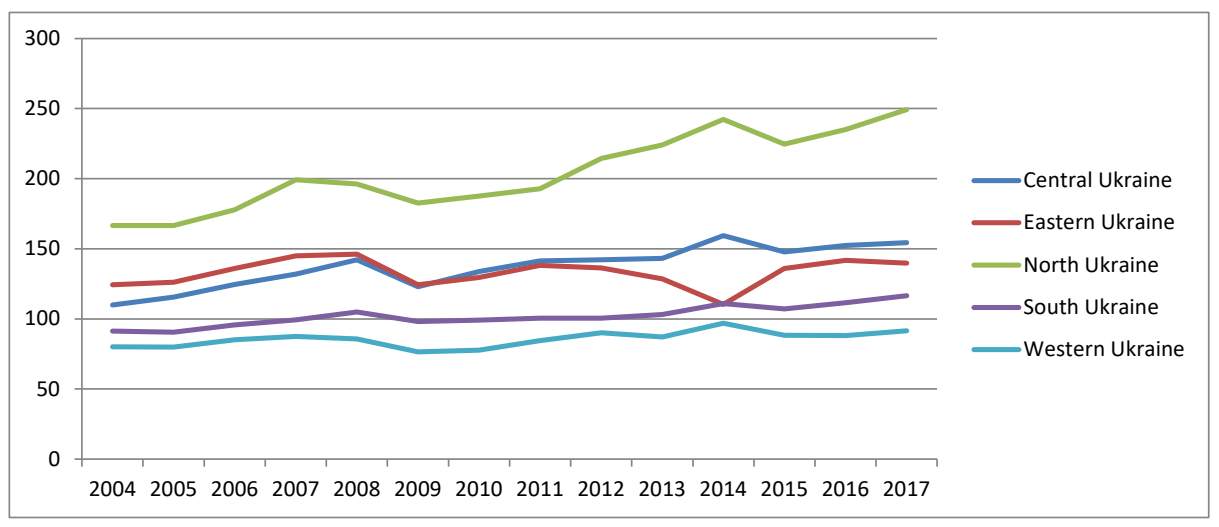

Source: authors' calculations based on data from www.ukrstat.gov.ua.

- all groups of oblasts (except Eastern Ukraine) show similar trends in labour productivity. Between 2004 and 2008, the value of this variable increased, but then decreased significantly in 2009. This decline was the result of both the global financial crisis and the gas conflict with Russia. Between 2010 and 2014 (i.e. until the Euromaidan), GDP per worker started to grow again. In 2015, labour productivity decreased, while an increase occurred in the years 2016-2017, as Ukraine recorded its first symptoms of economic recovery after the crisis caused by political perturbations following the Euromaidan (in 2016 Ukrainian GDP grew by $2.4 \%$ and in 2017 by $2.5 \%$ );

- the regions of Northern Ukraine, where the value of labour productivity increased from 166.6 thousand hryvnias in 2004 to 249.2 thousand hryvnias in 2017, noted the highest levels of GDP per employee. In Eastern Ukraine, labour productivity increased from 124.4 thousand hryvnias to 139.7 thousand hryvnias, in Central Ukraine from 110.0 thousand hryvnias to 154.4 thousand hryvnias, in the south 
from 91.3 thousand hryvnias to 116.6 thousand hryvnias, and in the west from 80.0 thousand hryvnias to 91.5 thousand hryvnias. This variable grew fastest in the most developed region - Northern Ukraine (3.1\% of the annual average), and the slowest in the industrial and mining regions of Eastern Ukraine (0.9\%).

Map 3 shows the geographical variance of wage distribution in Ukraine, while Figure 2 shows the trajectories of this variable in groups of oblasts in the years 20042015. The following conclusions can be drawn from the map and figure (cf. also e.g. Bolińska and Gomółka, 2018):

- as in the case of labour productivity, the highest wages were recorded in the capital city of Kyiv (on average 8,386.05 hryvnias in the years 2004-2017). The Donetsk (5,990.33 hryvnias), Dnipropetrovsk (5,481.32 hryvnias), Kiev (5,330.82 hryvnias), and Zaporozhsky (5,239.78 hryvnias) oblasts also noted high values of this variable;

Map 3. Wages in oblasts 2004-2017 (in hryvnias, prices as of 2016)

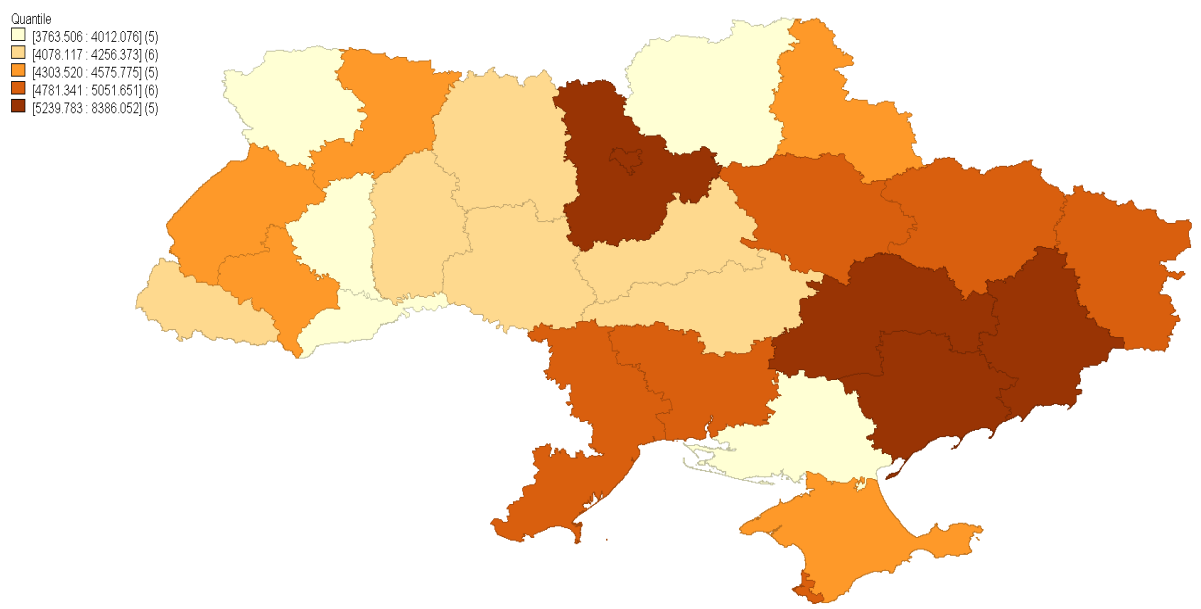

a For the Autonomous Republic of Crimea and Sevastopol, 2004-2013.

Source: authors' calculations based on data from www.ukrstat.gov.ua.

- the lowest wages were observed in the Chernivtsi (4,012.08 hryvnias), Volyn (4,005.88 hryvnias), and Ternopil (3,763.51 hryvnias) oblasts in Western Ukraine, in Kherson (4,009.69 hryvnias) in Southern Ukraine, and in Chernihiv $(4,000.78$ hryvnias) in the north of Ukraine; 
- spatial wage differentials in Ukraine overlapped with productivity differences to a large extent. The correlation coefficient between these variables amounted to 0.946, while the correlation coefficient between wages and unemployment rates discussed below, amounted to 0.586 ;

- wage trajectories in groups of oblasts were similar in shape to both the GDP and labour productivity trajectories, as labour productivity had a significant impact on wage levels in Ukraine;

- in Northern Ukraine, wages increased from 4,499.27 hryvnias in 2004 to 7,130.00 hryvnias in 2017, in Eastern Ukraine from 4,373.79 hryvnias to 5,881.58 hryvnias, in Central Ukraine from 3,741.65 hryvnias to 5,654.84 hryvnias, in Southern Ukraine from 3,669.01 hryvnias to 5,614.69 hryvnias, and in the poorest western regions of Ukraine from 3,176.35 hryvnias to 5,291.34 hryvnias. Therefore, the highest average annual wage dynamics were observed in Western Ukraine (4.0\%) and the lowest in Eastern Ukraine (2.3\%).

Figure 2. Wages and salaries in groups of regions (in hryvnias, prices as of 2016)

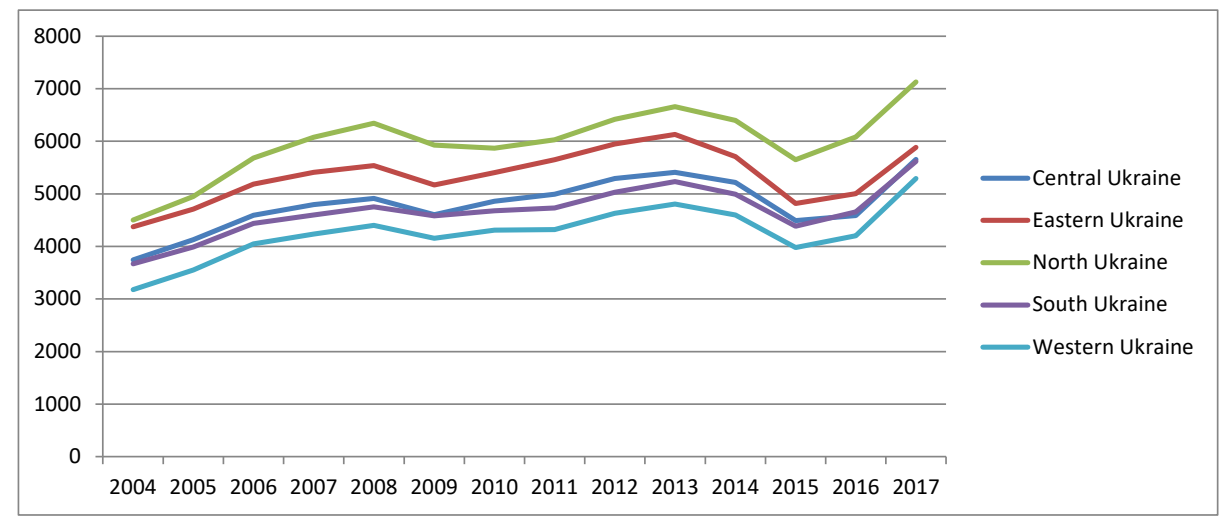

Source: authors' calculations based on data from www.ukrstat.gov.ua.

Map 4 illustrates the regional differentiation of unemployment rates in Ukrainian oblasts (2004-2017), while Figure 3 illustrates the trajectories of this variable in groups of oblasts. The following conclusions can be drawn from the map and the chart presented below (see also e.g. Lysiuk and Kaflevska, 2012; Paniuk, 2013; Homiak, 2015; Jarova, 2015; Tokarski et al., 2019):

- the lowest average unemployment rates in the studied period were observed in two cities with special status (Sevastopol 5.0\% and Kyiv 5.3\%), in the Crimean Autonomous Republic (5.7\%), and the periphery of Odessa (5.9\%) in the south of Ukraine. The highest unemployment was recorded in the Zhitomyr region 
(10.1\%) and in the Ternopil region (10.3\%) in the north of Ukraine, and the Rivne region (10.4\%) in Western Ukraine. High unemployment rates were also observed in the Chernihiv Oblast (9.8\%) in the north and in the Kirovograd Oblast (9.7\%) in Central Ukraine;

- the geographical variation in unemployment rates in Ukraine partly coincided with the geographical variation in labour productivity and wages, in the sense that, usually, the higher the productivity or wages, the lower the unemployment rates. The correlation coefficient between unemployment and labour productivity was -0.499 , and between unemployment rates and wages -0.586 ;

Map 4. Unemployment rates in groups of oblasts $2004-2017^{\text {a }}(\%)$

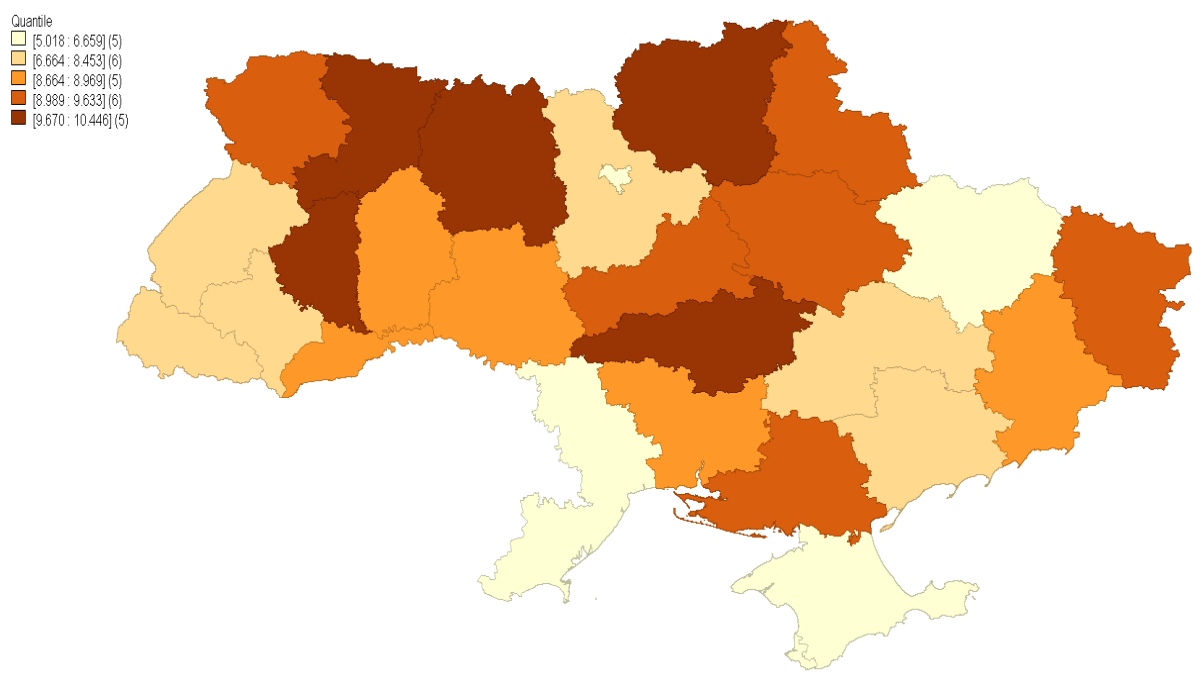

a For the Autonomous Republic of Crimea and Sevastopol, 2004-2013.

Source: authors' calculations based on data from www.ukrstat.gov.ua.

- the years 2004-2008 marked a good period for the Ukrainian economy as GDP grew rapidly, which translated into an increase in employment and a decrease in unemployment in all groups of oblasts. At that time, unemployment fell fastest in Western Ukraine (down by 2.7 percentage points) and slowest in Central Ukraine (1.7 percentage point). As a result, the difference between the group of oblasts with the highest unemployment (Western Ukraine) and the group with the lowest (Eastern Ukraine) decreased from 2.7 percentage points in 2004 to 2.1 percentage points in 2008; 
- the global financial crisis, combined with the Russian-Ukrainian gas conflict, brought about a one-year recession, which also resulted in a significant increase in unemployment in all groups of districts. At that time, it grew fastest in Central Ukraine (by 3.1 percentage points) and slowest in the south and west of Ukraine (by 1.8 percentage points);

Figure 3. Unemployment rates in groups of oblasts (\%)

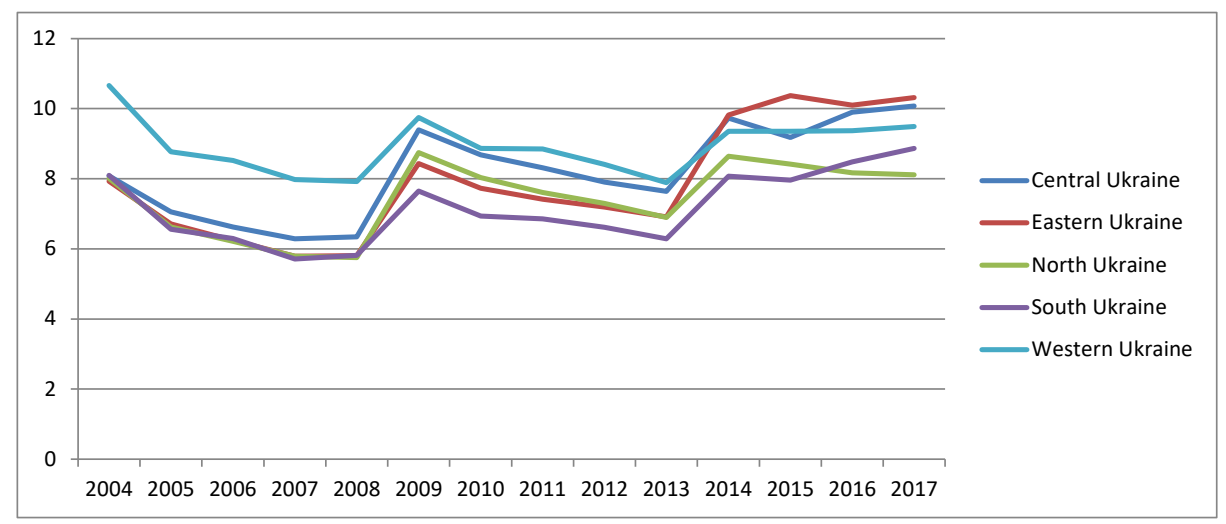

Source: authors' calculations based on data from www.ukrstat.gov.ua.

- the economic growth in Ukraine between 2010 and 2013 caused the unemployment rate to fall in all groups of oblasts. The largest falls in unemployment were recorded in Western Ukraine (1.9 percentage point) and the smallest in Southern Ukraine (1.4 percentage point);

- the economic and political-military crisis following the Euromaidan caused a surge in unemployment in all groups of Ukrainian oblasts. It increased from $7.9 \%$ in 2013 to $9.4 \%$ in 2014 in Western Ukraine, from 7.6\% to 9.7\% in Central Ukraine, from $6.9 \%$ to $9.8 \%$ in Eastern Ukraine, from $6.9 \%$ to $8.6 \%$ in Northern Ukraine and from $6.3 \%$ to $8.6 \%$ in Southern Ukraine;

- in the years 2015-2017, unemployment in all groups of Ukrainian oblasts stabilised, except for the regions of Northern and Southern Ukraine. In the north it started to grow slightly, and in the south, to fall slightly.

Figure 4 presents the coefficients of variation (quotient of standard deviation and unweighted arithmetic mean) of the macroeconomic variables analysed in Ukrainian oblasts in the years 2004-2017. The conclusion is that labour productivity was much more regionally varied than wages and unemployment rates. Moreover, the regional differentiation in labour productivity in Ukraine was on an upward trend, while the wage and unemployment rate differentials were similar and fairly stable over time. 
Figure 4. Labour productivity, wage, and unemployment rate variability rates in Ukraine

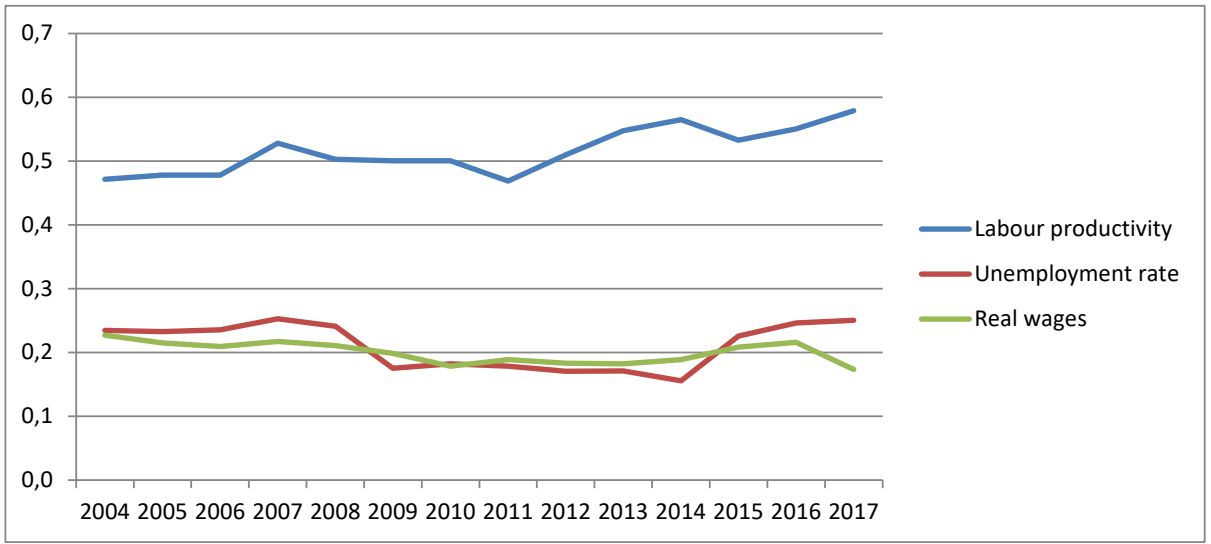

Source: authors' calculations based on data from www.ukrstat.gov.ua.

\section{Estimated parameters of the equations for changes in unemployment rates and wages}

In order to calculate the main determinants of the increase in unemployment rates, the definition of the unemployment rate provided by the following formula was applied (see also Tokarski, 2005):

$$
u_{i t}=\frac{U_{i t}}{U_{i t}+L_{i t}}=1 \frac{L_{i t}}{N_{i t}}
$$

where:

$U_{i t}$ - the number of unemployed,

$L_{i t}$ - the number of employed,

$N_{i t}$ - the supply of labour in the $i$-th province of the year $t$.

Equation (1) allows the increase in unemployment rates to depend on the level of the unemployment rate from the previous period and the rate of product growth. For this purpose, one can differentiate this equation to obtain the following relationship:

$$
u_{i t}^{\prime}=\frac{L_{i t}^{\prime} \cdot N_{i t}-L_{i t} \cdot N_{i t}^{\prime}}{N_{i t}^{2}}=\frac{L_{i t}}{N_{i t}} \cdot\left[\frac{N_{i t}^{\prime}}{N_{i t}}-\frac{L_{i t}^{\prime}}{N_{i t}}\right]
$$

Hence, and by the definition of the unemployment rate (1), the increase in the unemployment rate can be written as follows:

$$
u_{i t}^{\prime}=\left(1-u_{i t}\right) \cdot\left[\frac{N_{i t}^{\prime}}{N_{i t}}-\frac{L_{i t}^{\prime}}{N_{i t}}\right]
$$


Assuming, additionally, that the growth rate of the number of employed $\frac{L_{i t}^{\prime}}{N_{i t}}$ is an increasing function of the product growth rate $g$, and by using the relationship (2), we arrive at the following equation for the increase in the unemployment rate (see also Dykas et al., 2013):

$$
u_{i t}^{\prime}=\left(1-u_{i t}\right) \cdot\left[\frac{N_{i t}^{\prime}}{N_{i t}}-f(g)\right]
$$

where:

$$
\frac{L^{\prime}}{L}=f(g), f^{\prime}(g)>0
$$

Equation (3) demonstrates that, firstly, the increase in the unemployment rate is a decreasing function of the product growth rate $g$, and secondly, that if the labour supply growth rate is greater (smaller) than the growth rate of the number of employed, then the increase in the unemployment rate is a decreasing (increasing) function of the unemployment rate.

While analysing factors which determine wages, the following reasoning can be applied, which is a combination of the Solow 1979 efficiency wage model and the neoclassical economic growth model of Solow 1956 and its generalizations (Tokarski, 2005 or Dykas and Misiak, 2014). In the classic Solow 1979 efficiency wage model, an enterprise operating on the market aims to maximize the profit function described by the following formula:

$$
\pi\left(w_{i t}, L_{i t}\right)=F\left(\varepsilon\left(w_{i t}\right) \cdot L_{i t}\right)-w_{i t}
$$

where:

$w_{i t}, L_{i t} \quad-$ wages and number of employees in the $i$-th province in period $t$, $\varepsilon\left(w_{i t}\right) \quad-$ the efficiency of a typical employee, which is assumed to be an increasing wages function $\left(\varepsilon^{\prime}\left(w_{i t}\right)>0\right)$,

$F\left(\varepsilon\left(w_{i t}\right) \cdot L_{i t}\right) \quad$ - a neoclassical production function that describes the relationship between the so-called units of effective work (the product of the effectiveness of a typical employee $\varepsilon\left(w_{i t}\right)$ and the number of employees $L_{i t}$ ), and income.

The conditions necessary to maximise the profit function $\pi\left(w_{i t}, L_{i t}\right)$ are equal to

$$
\frac{d \varepsilon\left(w_{i t}\right)}{d w_{i t}} \cdot \frac{w_{i t}}{\varepsilon\left(w_{i t}\right)}=1
$$


In the next stage one can use the efficiency function of a typical employee with the given formula:

$$
\varepsilon\left(w_{i t}\right)=\left(\frac{w_{i t}-x_{i t}}{x_{i t}}\right)^{\alpha}
$$

where $\alpha \in(0,1)$, while $x_{i t}$ is the minimum wage that a typical employee is able to accept (the wage $x_{i t}$ is sometimes called the threshold wage).

In addition, it is assumed that the threshold wage is described by the following equation:

$$
x_{i t}=\left(1-a \cdot u_{i t}\right) \cdot w_{t}
$$

where:

$u_{i t}$ - the unemployment rate in the $i$-th province in period $t$,

$w_{i t}$ - the average wage in period $t$.

Equations (6) and (7) show that the effectiveness of a typical employee is an increasing function of a relative wage gap in the $i$-th labour market from the threshold wage operating in this market and the threshold wage is an increasing function of the average wage and a decreasing function of the unemployment rate. The following relationship between relative wages and the unemployment rate derives from Equations (5-9):

$$
\widetilde{w}_{i t}=\frac{1}{1-\alpha}-\frac{a}{1-\alpha} u_{i t}
$$

where:

$$
\widetilde{w}_{i t}=\frac{w_{i t}}{\bar{w}_{i t}} u_{i t}
$$

and $\bar{w}_{i t}$ is the average level of wages in the $i$-th market in year $t$.

Moreover, it can be assumed that wages are ultimately in line with the marginal product of labour (as is the case with the Solow 1956 economic growth models and its generalizations). Therefore, with the power production function of the CobbDouglas type, wages are proportional to work efficiency. Taking into account the above considerations, Equation (8) can be extended to the following equation:

$$
\widetilde{w}_{i t}=\alpha_{0}-\alpha_{1} \cdot u_{i t}+\alpha_{2} \cdot y_{i t}
$$


In view of this, the basic determinants of relative wages are labour productivity and unemployment rate.

Hence, the parameters of the following equations were estimated: ${ }^{6}$

$$
\Delta u_{i t}=\beta_{0}-\beta_{1} u_{i t-1}+\beta_{2} d_{\Delta u} u_{i t-1}+\beta_{3} \Delta \ln Y_{i t}
$$

and

$$
\widetilde{w}_{i t}=\alpha_{0}-\alpha_{1} u_{i t}+\alpha_{2} \ln y_{i t}
$$

where $u_{i t}$ stands for the unemployment rate in oblast $i$ in year $t, d \Delta u$ is a zero-one variable taking the value of 1 when the unemployment rate in circumference in year $t$ increased, and taking the value of zero in other cases (this variable makes it possible to distinguish trends in changes of the unemployment rate due to the direction of changes), $\Delta \ln Y_{i t}$ is the real GDP growth rate in oblast $i$ in year $t, w_{i t}$ indicates real average gross wages in oblast $i$ in year $t$, and $y_{i t}$ signifies the level of labour productivity in oblast $i$ in year $t$.

Equations (10-11) were estimated using the system estimator of the generalized moments method (SGMM). The idea of SGMM is to estimate the system of equations on both increments and levels. The instruments for explanatory variables in equations at levels are the delayed first increments of these variables.

The results of the estimation of parameters of Equations (10-11) for Ukraine, Left-Bank Ukraine, and Right-Bank Ukraine are presented in Tables 1-2.

The following conclusions can be drawn from the estimations presented in Table 1:

- the estimated signs of the parameters of the equation for the increase in unemployment rates are consistent with the theory of macroeconomics (with the exception of the parameter determining the impact of real GDP growth rate, which was statistically insignificant for Right-Bank Ukraine);

- analysing the estimates summarised in Table 1, a large asymmetry of the impact of unemployment rates from the previous period on the increase in unemployment rates could be observed, depending on whether previous unemployment rates increased or decreased in each of the discussed regions of Ukraine. The estimated parameter was higher (in terms of module) when unemployment rates in the previous period indicated a downward trend;

\footnotetext{
${ }^{6}$ For all parameters in Equations (10-11), except constants, which are implicitly assumed to be positive values.
} 
Table 1. Estimation of the parameters of the unemployment rate growth equation for Ukraine - Left-Bank Ukraine and Right-Bank Ukraine

\begin{tabular}{|c|c|c|c|c|c|c|}
\hline \multirow{2}{*}{ Explanatory variable } & \multicolumn{2}{|c|}{ Ukraine } & \multicolumn{2}{|c|}{ Left-Bank Ukraine } & \multicolumn{2}{|c|}{ Right-Bank Ukraine } \\
\hline & Coeff. & $t$-Stat & Coeff. & $t$-Stat & Coeff. & $t$-Stat \\
\hline$\Delta u_{i t-1}$ & 0.0671 & 1.75 & 0.0594 & 1.25 & 0.0108 & 0.23 \\
\hline constant ............................ & 0.0296 & 6.12 & 0.0274 & 4.28 & 0.0301 & 4.20 \\
\hline & & $(0.000)$ & & $(0.001)$ & & $(0.001)$ \\
\hline$u_{i t-1}$ & -0.4366 & 6.12 & -0.4319 & 4.42 & -0.4176 & $\begin{array}{r}-5.55 \\
(0.000)\end{array}$ \\
\hline$d_{\Delta u} u_{i t-1} \ldots \ldots \ldots \ldots \ldots$ & 0.2754 & $\begin{array}{r}21.02 \\
(0.000)\end{array}$ & 0.2877 & 8.66 & 0.2529 & 17.11 \\
\hline$\Delta \ln Y_{i t}$ & -0.0337 & $\begin{array}{r}-5.03 \\
(0.000)\end{array}$ & -0.0427 & $\begin{array}{r}-4.07 \\
(0.001)\end{array}$ & -0.0161 & $\begin{array}{r}-1.61 \\
(0.134)\end{array}$ \\
\hline Test AR(1) & -3 & & -2 & & & \\
\hline 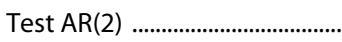 & & & & & & \\
\hline Hansen test ................... & $\begin{array}{r}0.8 \\
0\end{array}$ & & $\begin{array}{r}(0.9 \\
2\end{array}$ & & $\begin{aligned} 0.7 \\
0\end{aligned}$ & \\
\hline$F$ test .................................... & $\begin{array}{l}(0.8 \\
146 \\
(0.0\end{array}$ & & $\begin{array}{l}(0.4 \\
145 \\
(0.0\end{array}$ & & $\begin{array}{l}(0.9 \\
104 \\
0.0\end{array}$ & \\
\hline Number of observations ......... & & & & & & \\
\hline Number of instruments ............ & & 8 & & 8 & & \\
\hline
\end{tabular}

Note. The levels of statistical significance are given in brackets.

Source: authors' calculations based on data from www.ukrstat.gov.ua.

- the unemployment rate from the previous period (with the downward trend) had the strongest impact on the increase in the current unemployment rate for the entire Ukrainian economy, where each subsequent percentage point of the decrease in unemployment translated into a fall in current unemployment of about 0.44 percent. On the other hand, in the situation of rising unemployment rates in earlier periods, the strongest impact on the increase in current unemployment was observed in Left-Bank Ukraine, where each subsequent percentage point of increase in the unemployment rate caused an increase in current unemployment by about 0.29 percent;

- an increase in real GDP growth rate of 1 percentage point caused a decrease in unemployment rates in both the entire Ukrainian economy and in Left-Bank Ukraine of 0.034 and 0.043 percentage points, respectively. The estimated parameter determining the impact of the real GDP growth rate on the increase in current unemployment for Right-Bank Ukraine proved statistically insignificant;

- the Hansen test statistics and significance levels obtained for the studied regions in Ukraine do not give grounds to reject the zero hypothesis that all instruments in the model are not correlated with the random component. The Arellano-Bond test values for AR(1) and AR(2) (see also Arellano and Bond 1991) were also satis- 
factory, which indicates that in all estimation variants negative, statistically significant first order autocorrelation and statistically insignificant second order autocorrelation were obtained. This demonstrates the compatibility and effectiveness of the applied estimators.

The analysis of the results of the estimation of the relative wage equations (presented in Table 2) enables the following conclusions to be drawn:

- the estimated parameters of the wage model for the Ukrainian economy are statistically significant in the case of Left-Bank Ukraine. The parameter determining the impact of labour productivity on wages was statistically insignificant for Right-Bank Ukraine. The parameter describing the impact of the unemployment rate on wages also turned out to be statistically insignificant. Moreover, the scope of influence of independent variables on the level of wages proved consistent with the theory;

- the estimated parameters determining the level of impact of unemployment rates on relative wages for the entire Ukrainian economy were (in terms of module) higher than the estimates for Left-Bank Ukraine. In addition, the estimated parameter demonstrating the impact of labour productivity on relative wages for Right-Bank Ukraine was over 40\% higher than for the entire Ukrainian economy.

Table 2. Estimates of parameters of the relative wage equation for Ukraine, Left-Bank Ukraine and Right-Bank Ukraine

\begin{tabular}{|c|c|c|c|c|c|c|}
\hline \multirow{2}{*}{ Explanatory variable } & \multicolumn{2}{|c|}{ Ukraine } & \multicolumn{2}{|c|}{ Left-Bank Ukraine } & \multicolumn{2}{|c|}{ Right-Bank Ukraine } \\
\hline & Coeff. & $t$-Stat & Coeff. & $t$-Stat & Coeff. & $t$-Stat \\
\hline$\widetilde{w}_{i t-1}$ & 0.9222 & $\begin{array}{r}12.45 \\
(0.000)\end{array}$ & 0.9590 & $\begin{array}{r}10.83 \\
(0.000)\end{array}$ & 0.8547 & $\begin{array}{r}5.75 \\
(0.000)\end{array}$ \\
\hline 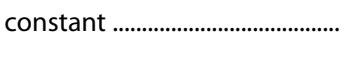 & -0.9159 & $\begin{array}{r}-1.31 \\
(0.191)\end{array}$ & -0.1317 & $\begin{array}{r}-2.10 \\
(0.036)\end{array}$ & -0.1305 & $\begin{array}{r}-1.08 \\
(0.281)\end{array}$ \\
\hline $\ln \left(y_{i t}\right)$ & 0.0421 & $\begin{array}{r}2.92 \\
(0.004)\end{array}$ & 0.0414 & $\begin{array}{r}1.90 \\
(0.048)\end{array}$ & 0.0603 & $\begin{array}{r}2.00 \\
(0.046)\end{array}$ \\
\hline$u_{i t}$ & -0.322 & $\begin{array}{r}-3.63 \\
(0.000)\end{array}$ & -0.2976 & $\begin{array}{r}-2.42 \\
(0.015)\end{array}$ & -0.0604 & $\begin{array}{r}-0.29 \\
(0.769) \\
\end{array}$ \\
\hline Test AR (1) .......................................... & \multicolumn{2}{|c|}{$\begin{array}{r}-1.74 \\
(0.082)\end{array}$} & \multicolumn{2}{|c|}{$\begin{array}{r}-1.51 \\
(0.130)\end{array}$} & \multicolumn{2}{|c|}{$\begin{array}{r}-1.96 \\
(0.050)\end{array}$} \\
\hline Test AR (2) & \multicolumn{2}{|c|}{$\begin{array}{r}-1.46 \\
(0.144)\end{array}$} & \multicolumn{2}{|c|}{$\begin{array}{r}-1.13 \\
(0.258)\end{array}$} & \multicolumn{2}{|c|}{$\begin{array}{r}-1.35 \\
(0.176)\end{array}$} \\
\hline 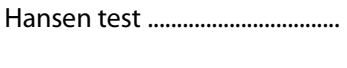 & \multicolumn{2}{|c|}{$\begin{array}{r}3.11 \\
(0.375)\end{array}$} & \multicolumn{2}{|c|}{2.86} & \multicolumn{2}{|c|}{$(0.211)$} \\
\hline$F$ test & \multicolumn{2}{|c|}{104.82} & \multicolumn{2}{|c|}{$\begin{array}{l}156.36 \\
(0.000)\end{array}$} & \multicolumn{2}{|c|}{$\begin{array}{l}146.92 \\
(0.000)\end{array}$} \\
\hline Number of observations ......... & \multicolumn{2}{|c|}{343} & \multicolumn{2}{|c|}{174} & \multicolumn{2}{|c|}{169} \\
\hline Number of instruments ........... & \multicolumn{2}{|c|}{7} & \multicolumn{2}{|c|}{7} & \multicolumn{2}{|c|}{7} \\
\hline
\end{tabular}

Note. The levels of statistical significance are in brackets.

Source: authors' calculations based on data from www.ukrstat.gov.ua. 


\section{Conclusions}

Geographical diversity of economic development and, consequently, regional labour markets in Ukraine are largely determined by historical factors. The most developed parts of the country are the largest cities (Kyiv, Dnipro, Kharkiv, Donetsk, Lugansk, Zaporozhye, Odessa, Mikolaiv, and Lviv). They have developed either their service sectors (Kyiv, Dnipro, Odessa, Mikolaiv, Lviv) or industrial sectors (Kharkiv, Zaporozhye, Donbas). All these cities (with the exception of Lviv) are located on the left bank of Ukraine or on the Black Sea. In other words, they are located in areas which, for over 200 years, were much more closely integrated with the Russian Empire, and later with the Soviet Union, than with the rest of Ukraine.

The trajectories of basic macroeconomic variables influencing the situation in regional labour markets depended both on the business cycle and the political cycle. Until 2008, the Ukrainian economy was developing rapidly as a result of marketoriented reforms undertaken at the beginning of the $21^{\text {st }}$ century. Then came recession, caused by the global financial crisis and the gas conflict with Russia, which led to a fall in GDP, labour productivity, and wages, and a rise in unemployment. After that, the Ukrainian economy returned onto a path of economic growth, which lasted until the outbreak of Euromaidan. The Russian annexation of the Crimean Peninsula and the military conflict with pro-Russian separatists in Donbass destabilised Ukraine, which caused the country to plunge into deep recession, from which the Ukrainian economy began to emerge only in 2016.

The regional variation in labour productivity in Ukraine was greater in the studied period than the wage and unemployment differences. The reason behind this situation is threefold. Firstly, the differentiation in labour productivity resulted mainly from differences in employment infrastructure and the extent of gravity effects (which is largely dependent on the effect of the centuries-old urban network, cf. Chugaievska et al., 2017). Secondly, the public sector of the Ukrainian economy was characterised by hidden unemployment, which added to the smaller geographical variation in unemployment rates. Unemployment was much more evenly distributed geographically than employment infrastructure or labour productivity. Thirdly, the wage gap in Ukraine was much smaller than the productivity gap, because, as in the case of Poland (cf. e.g. Trojak and Tokarski, 2013), wages in the public sector were quite uniform throughout the country.

The estimates of the parameters of the equation for the increase in unemployment rates show that these increases were most strongly influenced by the values of unemployment rates from the previous period when these rates were on an upward trend for Left-Bank Ukraine. In the situation where the unemployment rates were on 
a downward trend, then unemployment rates from the previous period had the strongest impact on the current increase in unemployment for the entire Ukrainian economy. The GDP growth rate had a stronger impact on the increase in unemployment in Left-Bank Ukraine, while the parameter describing the impact of the GDP growth rate on the increase in the unemployment rate for Right-Bank Ukraine proved statistically insignificant. In the case of relative wage equations, the impact of labour productivity on relative wages in Left-Bank Ukraine and the entire economy was symmetrical and about $20 \%$ lower than in Right-Bank Ukraine. Moreover, the unemployment rate had a stronger impact on relative wages in the entire economy than on Left-Bank Ukraine, while the parameter determining the impact of the unemployment rate on the relative wages of Right-Bank Ukraine proved statistically insignificant. To sum up, the weaker impact of GDP growth rates on increases in unemployment rates and labour productivity on wages can be explained by the existence of hidden unemployment in the public sector of the economy and low regional diversity of wages in this sector (see also Chugaievska and Tokarski, 2018).

\section{References}

Arellano M., Bond S., (1991), Some tests of specification for panel data: Monte Carlo evidence and an application to employment equations, Review of Economic Studies, 58(2), 277-297. DOI: $10.2307 / 2297968$.

Blundell R., Bond S., (1998), Initial conditions and moment restrictions in dynamic panel data models, Journal of Econometrics, 87(1), 115-143. DOI: 10.1016/S0304-4076(98)00009-8.

Bolińska M., Gomółka A., (2018), Determinanty przestrzennego zróżnicowania płac w obwodach Ukrainy Zachodniej w latach 2004-2015, Modern Management Review, 5(3), 31-44. DOI: 10.7862/rz.2018.mmr.22.

Chugaievska N., Tokarski T., (2018), Wpływ zmian PKB na przestrzenne zróżnicowanie bezrobocia na Ukrainie, Wiadomości Statystyczne, 3, 50-68. DOI: 10.5604/01.3001.0014.0639.

Chugaievska S., Chugaievska N., Tokarski T., (2017), Analyse statistique de l'impact de l'effet gravitationnel sur la diversification du développement économique de l'Ukraine, Revue Internationale Des Economistes De Langue Française, 2(2), 72-95.

Dykas P., Misiak T., (2014), Determinanty podstawowych zmiennych rynku pracy w polskich powiatach w latach 2002-2011, Gospodarka Narodowa, 6, 57-80. DOI: 10.33119/GN/100881.

Dykas P., Misiak T., Tokarski T., (2013), Czynniki kształtujące regionalne zróżnicowanie stóp bezrobocia rejestrowanego $\mathrm{w}$ Polsce $\mathrm{w}$ latach 2002-2010, Humanities and Social Science, 1, 9-21. DOI: 10.7862/rz.2013.hss.1.

Hrycak J., (2000), Historia Ukrainy 1772-1999. Narodziny wspótczesnego narodu, Instytut Europy Środkowo-Wschodniej, Lublin.

Homiak M. A., (2015), Analiz suchasnoho stanu zainiatosti ta bezrobottia v Ukraini, Aktualny problemy philosophi ta sociolohii, 4, 752-756. 
Hud B., (2018), Ukraińcy i Polacy na Naddniestrzu, Wolyniu i w Galicji Wschodniej w XIX i pierwszej połowie XX wieku, Pracownia Wydawnicza, Warszawa.

Jarova L. G., (2015), Analiz rivnia bezrobottia v Ukraini ta napriamki ioho podolannia, Hlobalny ta nacionalny problemy ekonomiki, 4, 424-431.

Konstytucja Ukrainy, www.libr.sejm.gov.pl/tek01/txt/konst/ukraina.html.

Lysiuk O. S., Kaflevska S. G., (2012), Bezrobottia iak socialno-ekonomichna problema nasielienija Ukrainy. Ekonomichni nauki 4, 48-53.

Paniuk T., (2013), Vykorystannija svitovoho dosvitu dlja vyrishennija problem rynku praci v Ukraini, Ekonomika ta managment, 10, 178-187.

Pustovoit O. W., (2016), Ukrainska ekonomika: haotichni ta cyklichni kolyvannija dobhostrokovoho trendu zrostannija, Ekonomika i prohnozuvannija, 2, 86-109. DOI: 10.15407/eip2016.02.083.

Serczyk W. A., (2001), Historia Ukrainy, Zakład Narodowy im. Ossolińskich, Wrocław, Warszawa, Kraków.

Steiger D., Stock J., (1997), Instrumental Variables Regression with weak Instruments, Econometrica, 65(3), 557-586. DOI: 10.3386/t0151.

Tokarski T., (2005), Statystyczna analiza regionalnego zróżnicowania wydajności pracy, zatrudnienia i bezrobocia w Polsce, Wydawnictwo Polskiego Towarzystwa Ekonomicznego, Warszawa.

Tokarski T., Chugaievska S., Chugaievska N., (2019), Determinanty przestrzennego zróżnicowania płac na Ukrainie, Wiadomości Statystyczne 5, 17-33. DOI: 10.5604/01.3001.0013.8503.

Trojak M., Tokarski T., (ed.), (2013), Statystyczna analiza przestrzennego zróżnicowania rozwoju ekonomicznego i społecznego Polski, Wydawnictwo Uniwersytetu Jagiellońskiego, Kraków. 